1

2

3

4

5

6

7

8

9

10

11

12

13

14

\title{
Preservative effect of an organic acid-icing system on
} chilled fish lipids

5 Bibiana García-Soto ${ }^{1}$, Minia Sanxuás ${ }^{2}$, Jorge Barros-Velázquez ${ }^{2}$, José R. Fuertes-Gamundi ${ }^{1}$ and Santiago P. Aubourg ${ }^{3, *}$

${ }^{1}$ Cooperativa de Armadores de Pesca del Puerto de Vigo (ARVI), Vigo, Spain

${ }^{2}$ Department of Analytical Chemistry, Nutrition and Food Science, Escuela de Ciencias 8 Veterinarias, Universidad de Santiago de Compostela, Lugo, Spain

$29{ }^{3}$ Department of Food Technology. Instituto de Investigaciones Marinas (CSIC), Vigo, Spain

$1 \quad$ * Correspondent: saubourg@iim.csic.es 


\section{SUMMARY}

2

3 This study provides a first approach concerning a novel chilling strategy, which

4 employs a mixture of different preservative organic acids (ascorbic, citric and lactic) in

5 the icing medium. Thus, ice prepared from water including two different concentrations

6 of a commercial acid mixture-formula (800 ppm and $400 \mathrm{ppm}$; C-800 and C-400

7 conditions, respectively) were applied as icing system to three important commercial

8 fish lean species (hake, Merluccius merluccius; megrim, Lepidorhombus whiffiagonis;

9 angler, Lophius piscatorius). Lipid oxidation (peroxide value; thiobarbituric acid index;

10 fluorescent compound formation) and hydrolysis (free fatty acid formation) were

11 evaluated throughout the chilling time (up to 12-15 days) and compared to results

12 obtained in fish kept under traditional ice prepared only from water (C-0 condition); a

13 complementary sensory evaluation was carried out. As a result of employing the C-800

14 icing condition, a partial inhibition of lipid oxidation and hydrolysis development was

15 obtained that was accompanied by a shelf life enhancement in all cases. Further research

16 taking into account the complementary action of the present organic acids is envisaged.

17 According to the lipid damage analysis undergone, lipid hydrolysis showed to be a more

18 relevant event than lipid oxidation in all fish species tested. 


\section{PRACTICAL APPLICATIONS}

2

3 The actual increasing consumer's demand for high quality fresh products has led to the

4 search for valuable treatments that provide enhancing commercial possibilities. This

5 study provides a first approach to the employment of a novel chilling strategy consisting

6 of an icing system including a mixture of organic acids (ascorbic, citric and lactic),

7 these providing complementary preservative properties (acidulants, antioxidants and

8 antimicrobians). As a result of employing this icing condition, a partial inhibition of

9 lipid oxidation and hydrolysis development was obtained that was accompanied by a

10 shelf life enhancement during the chilled storage of three important lean fish species

11 (hake, megrim and angler). Further studies focused to the optimised employment of

12 these acids by means of this icing strategy are envisaged, taking into account the

13 endogenous antioxidant composition in tested fish species (synergism possibility

14 analysis) and the diffusion rate of organic acids from the icing medium to the fish

15 muscle.

18 Running Head: Organic acid-icing and chilled fish lipids

19 Keywords: Fish, chilling, ascorbic, citric, lactic, lipid damage 


\section{INTRODUCTION}

2

3 Marine products constitute a highly perishable food group. Deterioration of fish species

4 begins immediately upon capture, and the degree to which it continues depends directly

5 on storage conditions. Flake ice has been the most employed method to cool and store

6 fish products and partially inhibit detrimental effects on the commercial value.

7 However, significant deterioration of sensory quality and nutritional value has been

8 detected in chilled fish as a result of different damage pathways, such as endogenous

9 enzymatic activity, microbial development and lipid oxidation [1, 2].

10 Assurance of both high quality and safety of chilled seafood is an important actual 11 challenge for fish traders and food technologists. To retard fish damage as long as 12 possible, and accordingly extend shelf life, a wide number of preservative strategies to 13 be combined to flake ice chilling have been tested satisfactorily such as previous

14 chemical and physical treatments $[3,4]$ and employment of preservative packaging [5, $156]$.

16 Among chemical treatments, natural organic acids have shown to represent a relevant

17 choice because of their easy availability, low commercial cost and wide range of 18 permitted concentrations for their use. Thus, ascorbic and citric acids (AA and CA, 19 respectively) and their salts are widely known for their role as chelators, acidulants in

20 biological systems and synergists of primary antioxidants, so that a profitable effect on 21 fish oil and emulsions [7, 8], minced fish [9, 10], fish fillets [11, 12] and whole fish [13] 22 have been observed. Further, lactic acid (LA) has been reported to be effective in 23 suppressing Gram-negative bacteria, which are known to be the most important fish 24 spoiler group; thus, LA pre-treatment has shown to be effective in preserving and 25 extending shelf-life in fish fillets $[14,15]$ and coated fish [16]. 
1 Marine lipids are comprised by highly unsaturated fatty acids that are known to be very

2 prone to oxidation. During fish chilled storage, lipids have been reported to undergo

3 hydrolysis and oxidation reactions that can lead to important losses of sensory and

4 nutritional qualities with an important impact on the commercial value $[17,18]$. The

5 present research focuses the lipid damage undergone by three important lean fish

6 species (hake, Merluccius merluccius; megrim, Lepidorhombus whiffiagonis; angler,

7 Lophius piscatorius) during the chilled storage. The study provides a first approach

8 concerning a novel strategy employing ice prepared from an aqueous solution including

9 AA, CA and LA as chilling system. Lipid oxidation and hydrolysis were evaluated

10 throughout the storage time and compared to results obtained in fish kept under

11 traditional ice only prepared from water. In a previous experiment [19], ice including

12 polyphenolic compounds from rosemary and oregano aqueous extracts was applied to a

13 fatty fish species (Chilean jack mackerel; Trachurus murphy); the employment of such

14 icing system as chilling medium led to a partial inhibition of lipid oxidation.

\section{MATERIALS AND METHODS}

\section{$\underline{\text { 2.1. Preparation of icing systems including organic acids }}$}

20 A commercial formula (BPS2) including an organic acid-mixture was supplied by

21 ATALANTA S.L. (Vigo, Spain) for employment in the present research. Such a

22 product consists of a water-soluble viscous liquid including AA, CA and LA (1 meq

$23 \mathrm{acid} / 120 \mathrm{mg}$ product) in glycerol, being regarded as safe (GRAS) for use in foods

24 according to European and American administrations [20, 21]. 
1 Preliminary trials were carried out in order to assess the most convenient product

2 concentration to be included in the icing system. For it, the effect on sensory acceptance

3 (appearance, texture, gills, odour and colour) of a wide range (70-2000 ppm) of aqueous

4 concentrations of the organic acid-mixture was checked. As a result, $800 \mathrm{ppm}$ and 400

5 ppm concentrations showed to provide the most convenient results. Accordingly, both

6 concentrations were chosen to be employed in the present research (C-800 and C-400

7 conditions, respectively) and be compared to fish kept under traditional ice prepared

8 from water (C-0 condition).

9

$10 \quad$ 2.2. Raw fish, processing and sampling

11 Fresh hake (Merluccius merluccius; 96 individuals), megrim (Lepidorhombus

12 whiffiagonis; 78 individuals) and angler (Lophius piscatorius; 78 individuals) were

13 caught near the Galician Atlantic coast (North-western Spain) in Autumn 2009 and

14 transported on ice to the laboratory. The length and weight of the fish specimens was

15 included in the following ranges: $32-34 \mathrm{~cm}$ and 200-300 $\mathrm{g}$ (hake), 19-23 cm and 90-120

$16 \mathrm{~g}$ (megrim) and 24-27 $\mathrm{cm}$ and 275-350 $\mathrm{g}$ (angler).

17 Upon arrival in the laboratory, six individual fishes of each species were separated and

18 considered as starting raw fish (day 0$)$; for it, three $(n=3)$ different groups ( 2 individuals

19 per group) were considered for each species and analysed independently. The remaining

20 fish were divided into three batches (30 individuals in each batch for hake; 24

21 individuals per batch for both megrim and angler), placed in boxes and directly

22 surrounded by different kinds of ice (C-800, C-400 and C-0 conditions, respectively),

23 according to the results obtained in the above mentioned preliminary trials.

24 In each case, the fish individuals were surrounded by ice at a 1:1 fish-to-ice ratio. All

25 batches were placed in a refrigerated room $\left(4^{\circ} \mathrm{C}\right)$. Boxes employed allowed draining 
1 and ice was renewed when required. Fish samples from the different icing conditions

2 were taken for analysis on days 1, 5, 8 and 12; day 15 was also considered in the case of

3 hake. At each sampling point, six individuals of each species per batch were taken for

4 analysis, so that three $(n=3)$ independent groups (two individuals per group) were

5 considered for each batch and species.

6

$7 \quad$ 2.3. Composition analyses

8 Moisture content was determined by the difference between the weight of fresh

9 homogenised white muscle (1-2 g) and the weight recorded after $4 \mathrm{~h}$ at $105^{\circ} \mathrm{C}$. Results

10 were expressed as $\mathrm{g}$ water/ $100 \mathrm{~g}$ muscle.

11 Lipids were extracted from the fish white muscle by the Bligh and Dyer [22] method,

12 by employing a single-phase solubilisation of the lipids using a chloroform-methanol

13 (1:1) mixture. Quantification results were expressed as g lipid/ $100 \mathrm{~g}$ muscle.

$15 \quad$ 2.4. Lipid oxidation measurement

16 The peroxide value (PV) was determined in the lipid extract by peroxide reduction with

17 ferric thiocyanate, according to the Chapman and McKay [23] method. Results were expressed as meq active oxygen/ $\mathrm{kg}$ lipids.

19 The thiobarbituric acid index (TBA-i) was determined according to Vyncke [24]. This

20 method is based on the reaction between a trichloracetic acid extract of the fish muscle

21 and thiobarbituric acid. Content on thiobarbituric acid reactive substances (TBARS)

22 was spectrophotometrically measured at $532 \mathrm{~nm}$ and results were expressed as $\mathrm{mg}$

23 malondialdehyde/ kg muscle.

24 Formation of fluorescent compounds was determined by measurements at 393/463 nm

25 and $327 / 415 \mathrm{~nm}$ as described by Aubourg et al. [25]. The relative fluorescence (RF) was 
1 calculated as follows: $\mathrm{RF}=\mathrm{F} / \mathrm{F}_{\mathrm{st}}$, where $\mathrm{F}$ is the fluorescence measured at each

2 excitation/ emission maximum, and $F_{s t}$ is the fluorescence intensity of a quinine

3 sulphate solution $\left(1 \mu \mathrm{g} / \mathrm{ml}\right.$ in $\left.0.05 \mathrm{M} \mathrm{H}_{2} \mathrm{SO}_{4}\right)$ at the corresponding wavelength. The

4 fluorescence ratio (FR) was calculated as the ratio between the two RF values: FR =

$5 \mathrm{RF}_{393 / 463 \mathrm{~nm}} / \mathrm{RF}_{327 / 415} \mathrm{~nm}$. The FR value was determined in the aqueous phase resulting

6 from the lipid extraction of the fish muscle [22].

7

\section{$8 \quad \underline{\text { 2.5. Lipid hydrolysis assessment }}$}

9 Free fatty acid (FFA) content was determined in the lipid extract of the fish muscle by 10 the Lowry and Tinsley [26] method based on complex formation with cupric acetate-

11 pyridine followed by spectrophotometric $(715 \mathrm{~nm})$ assessment. Results were expressed 12 as g FFA/ 100 g lipids.

\section{$14 \quad$ 2.6. Sensory analysis}

15 Sensory analysis was conducted by a sensory panel consisting of five experienced 16 judges, according to guidelines concerning fresh and refrigerated fish [27]. Panellists

17 had been involved in sensory analysis of different kinds of fish foods during the last 10

18 years. Previously to the present experiment, a special training was carried out on chilled

19 hake, megrim and angler.

20 Four categories were ranked: highest quality (E), good quality (A), fair quality (B) and

21 unacceptable quality (C). Sensory assessment of the fish included the following 22 parameters: eyes, gills, external odour, muscle odour (raw and cooked fish) and taste 23 (cooked fish). At each sampling time, the fish muscle portions were presented to 24 panellists in individual trays and were scored individually. The panel members shared 25 samples tested. 


\section{$2 \quad$ 2.7. Statistical analysis}

3 Data $(\mathrm{n}=3)$ obtained from the different chemical analyses were subjected to the 4 ANOVA method $(\mathrm{p}<0.05)$ to explore differences by two different ways: icing 5 conditions effect and chilling time effect (Statsoft, Statistica, version 6.0, 2001); 6 comparison of means was performed using a least-squares difference (LSD) method.

7 Correlation analysis among parameters (chilling time, lipid damage indices and sensory 8 acceptance) was also carried out. In them, linear fittings are expressed; otherwise, the 9 kind of fitting is mentioned.

\section{RESULTS AND DISCUSSION}

\section{3.1. Moisture and lipid contents}

15 Moisture contents obtained for the three species are expressed in Table 1. Values 16 included in the 79-81 g/ $100 \mathrm{~g}$ muscle range were observed in starting raw fish, which 17 agrees to results previously obtained in the same species and related lean fish species 18 [25, 28-31]. Comparison among fish individuals from the different icing conditions 19 tested provided some differences; however, a clear pattern could not be concluded, so 20 that no effect $(\mathrm{p}>0.05)$ of the organic acid presence in ice could be inferred on water 21 content in fish muscle. Meantime, an increasing $(\mathrm{p}<0.05)$ moisture value could be 22 observed in all kinds of samples with chilling time; thus, good correlation values were 23 obtained between both parameters (chilling time and moisture content) for hake $\left(\mathrm{r}^{2}=\right.$ 24 0.93-0.94, logarithmic fitting) and megrim $\left(\mathrm{r}^{2}=0.91-0.94\right)$, being fair in the case of 25 angler $\left(r^{2}=0.83-0.93\right.$, logarithmic fitting). This increase can be explained as a result of 
1 contact with the ice medium and has already been described in previous research related

2 to lean fish species [25].

3 Concerning the lipid content of fish muscle, hake and megrim provided a higher value

4 range (0.55-0.70 g/ $100 \mathrm{~g}$ muscle) than angler (0.40-0.45 g/ $100 \mathrm{~g}$ muscle). This result

5 agrees to the fact that a higher $(\mathrm{p}<0.05)$ moisture content was observed for this latest

6 species, according to a known inverse ratio between both (water and lipids) constituent

7 proportions [28]. Mean values obtained for lipid content showed some decreasing

8 tendency with icing time; however, differences were not found significant $(\mathrm{p}>0.05)$ as a

9 result of marked fish-to-fish differences.

\section{$11 \quad$ 3.2. Lipid oxidation assessment}

12 Lipid oxidation was studied by means of different quality indices corresponding to

13 different steps included in the fish lipid oxidation development.

14 Related to hake chilled storage (Table 2), C-800 condition led in most cases to

15 individual fishes showing lower mean values for peroxides, TBARS and fluorescence

16 development than their corresponding fish samples from C-400 and C-0 conditions;

17 when compared to control fish, such differences were found significant in most cases,

18 so that an inhibitory effect on lipid oxidation development could be inferred for the

19 organic acid presence in ice at the highest concentration. Concerning C-400 condition,

20 an inhibitory effect could also be concluded according to the FR assessment (days 1, 12 21 and 15).

22 Taking into account the peroxide (lower scores than 5.0 in all cases) and the TBARS

23 (lower scores than 0.9 in all cases) values, hake lipid oxidation can be considered low in

24 all kinds of fish samples, according to previous research concerning chilled storage of

25 this species $[29,30]$. In general terms, increasing values could be observed with time in 
1 all kinds of samples for the different quality indices. However, in the case of PV and

2 TBA-i, some decreases in advanced chilled stages (days 12 and 15) could also be

3 observed; such decreases can be explained on the basis of the high reactivity of

4 molecules to be measured under both quality indices [25, 32]. As a result, the best

5 correlation values between chilling time and lipid oxidation development could be

6 observed when considering the FR assessment $\left(\mathrm{r}^{2}=0.82-0.87\right)$, also in agreement to

7 previous research [30].

8 Related to megrim (Table 3), an inhibitory effect of both mixture concentrations (C-400

9 and C-800 conditions) could be observed on fluorescent compound formation in the 8-

10 12-day period. However, peroxide and TBARS formation did not provide a definite

11 tendency during the 0-8-day period; at the end of the experiment, higher values were

12 found for fish kept under C-400 condition.

13 In this case (megrim fish), lipid oxidation development can also be considered low

14 according to the peroxide development (scores below 7.5 in all cases) and TBARS

15 formation (scores below 1.0 in all cases). Chilling time led in most cases to increases for

16 the PV and TBA-i determinations; however, some decreasing values were produced in

17 advanced chilled stages (day 12), that can be explained again as a result of breakdown

18 or interaction of molecules susceptible to be measured under such indices. As with

19 hake, FR assessment provided in all icing systems a gradual increase so that a good

20 correlation value could be found between chilling time and FR parameter $\left(r^{2}=0.92-\right.$

21 0.93); this quality index already showed to be accurate during a previous chilled storage 22 experiment of megrim [33].

23 For chilled angler (Table 4), a lower $(\mathrm{p}<0.05)$ peroxide formation could be observed in

24 individuals kept under C-800 condition when compared to their counterparts under

25 control conditions; such a conclusion is also valid in most cases for C-400 condition 
1 fish. However, this inhibitory effect could not be observed for the two other indices

2 (TBA-i and FR), which did not provide a definite effect $(\mathrm{p}>0.05)$ for the organic acid

3 presence in ice during the chilled storage of angler.

4 Present results conclude that lipid oxidation development has shown to be specially low

5 in angler fish. Peroxide scores remained in all cases under 4.0 value, while TBARS

6 formation showed in all cases scores under 0.20 value. Additionally, peroxide value

7 showed a general decrease at advanced stages (day 12) of chilled storage. It is inferred

8 that lipid oxidation development is not a relevant damage mechanism in this species

9 under chilling conditions. This conclusion agrees to the above mentioned low lipid

10 content (0.40-0.45 g/ $100 \mathrm{~g}$ muscle). In spite of the low primary and secondary lipid

11 oxidation development, FR assessment showed an increasing tendency in fish samples

12 corresponding to all icing conditions; as a result, a fair correlation value was obtained

13 between chilling time and FR $\left(r^{2}=0.83-0.89\right.$, quadratic fitting).

14 The partial inhibition of oxidation development found in the present research for the

15 three species as a result of the organic acid presence in ice agrees to previous research

16 where $\mathrm{AA}$ and $\mathrm{CA}$ have shown a profitable antioxidant effect when applied as a

17 preliminary treatment. Thus, CA and its salts have shown to play a synergist role with

18 primary antioxidants and oxygen scavengers during the refrigerated [10, 34] and frozen

$19[12,13]$ storage of marine species. In the same way, AA and its salts have been reported

20 to act as antioxidants in fish oil [7], minced fish [9], fish fillets [11] and whole fish [13]

21 because of their oxygen scavenger and reducing roles.

22 Lipid oxidation development has been recognised as a complex process where different

23 kinds of molecules are produced, most of them unstable, susceptible to breakdown and

24 originate lower weight compounds, or react with other molecules (nucleophilic-type,

25 mostly) present in the fish muscle; as a result, determination of each kind of compound 
1 cannot always provide an accurate method for the quality loss assessment in fish. In the

2 present research, all species showed a low primary and secondary lipid oxidation

3 compound formation, that was accompanied by some content decreases in advanced

4 chilled stages. The electrophilic character of such lipid oxidation compounds has lead

5 them to interact with food constituents possessing nucleophilic functions [25, 32], so

6 that FR assessment (tertiary lipid oxidation compounds) has provided the best

7 correlation values with chilling time in all three species tested.

\section{$9 \quad$ 3.3. Lipid hydrolysis development}

10 Although lipid hydrolysis has been shown to occur during fish chilled storage, the

11 formation of FFA itself does not lead to nutritional losses. However, accumulation of

12 FFA has been related to some extent to lack of acceptability, because FFA are known to

13 have detrimental effects on protein properties [35] and oxidise faster than higher

14 molecular weight lipid classes (namely, triglycerides and phospholipids) by providing a

15 greater accessibility (lower steric hindrance) to oxygen and other pro-oxidant molecules

16 [36]. In addition, previous research has shown FFA assessment to be an accurate tool

17 for assessing freshness loss during lean fish chilling [37]. According to this, examining

18 the extent of lipid hydrolysis was deemed important to the present research.

19 FFA formation showed a lower $(\mathrm{p}<0.05)$ formation in hake fish kept under $\mathrm{C}-800$

20 condition when compared to its counterpart corresponding to C-400 and C-0 conditions

21 (Fig. 1). However, no inhibitory effect $(\mathrm{p}>0.05)$ could be observed as a result of

22 employing ice including a $400 \mathrm{ppm}$ concentration of the organic acid-mixture. As in

23 previous research [30], lipid hydrolysis development in chilled hake provided an

24 increasing tendency with chilling time in all icing conditions, so that a good correlation

25 value was obtained between both parameters $\left(r^{2}=0.93-0.95\right.$, quadratic fitting). 
1 A similar result could be concluded for megrim fish (Fig. 2). Thus, a lower $(\mathrm{p}<0.05)$

2 FFA formation could be observed in the 8-12-day period for individual fishes

3 corresponding to C-800 condition when compared to their counterpart samples from C-

4400 and C- 0 conditions. Again, no effect could be attributed to the C-400 condition, as

5 no differences ( $>00.05)$ could be inferred with fish samples corresponding to control.

6 An important FFA formation was observed in chilled megrim under any of the icing

7 conditions studied, so that a good correlation value was obtained between both

8 parameters (chilling time and FFA content) for the different icing conditions $\left(r^{2}=0.93-\right.$

9 0.94, quadratic fitting). A marked lipid hydrolytic activity had already been shown

10 during a previous chilled experiment of megrim [33].

11 Concerning angler fish (Fig. 3), a lower $(\mathrm{p}<0.05)$ hydrolysis development could be

12 observed for fish corresponding to the C-800 condition when compared to fish kept

13 under the two other icing conditions. As for hake and megrim, C-400 condition did not

14 provide $(\mathrm{p}>0.05)$ an inhibitory effect on FFA formation. A progressive formation of

15 FFA was produced with chilling time in all cases; thus, good correlation values were

16 obtained between chilling time and FFA content $\left(r^{2}=0.91-0.92\right)$.

17 FFA formation during chilling storage has been reported to be produced as a result of 18 endogenous enzyme activity and microbial activity [1, 17]. Before the end of the

19 microbial lag phase (up to 6-9 days, depending on several factors), FFA formation has

20 been reported to be produced mostly as a result of endogenous enzyme (namely, lipases

21 and phospholipases) activity. Later on, microbial activity should gain importance, so

22 that FFA formation is then mostly produced as a result of bacterial catabolic processes.

23 According to this profile, present results on FFA formation in hake and megrim show a

24 first stage of low FFA formation (0-8 days and 0-5 days, respectively) corresponding

25 mostly to the endogenous enzymatic activity. Then, a marked increase is produced (a 
1 quadratic fitting has been mentioned above for both species) that could be explained as

2 a result of the microbial activity development. In the case of angler, a marked difference

3 between both FFA formation phases is not apparent, so that a progressive FFA content

4 increase is observed (a linear fitting has been mentioned above) throughout the whole

5 experiment.

6 Concerning the effect of the organic acid presence in the icing system, a microbial

7 activity inhibition during the second phase of the chilling time has been observed in the

8 three species tested. To our knowledge, this preservative effect is described for the first

9 time during the chilled storage of lean fish species. As being molecules supporting

10 acidulant properties, all three acids can be found responsible for this microbial

11 inhibition [1, 4]. However, this effect has been reported to be specially important in the

12 case of LA, as being recognised as effective in suppressing Gram-negative bacteria

13 activity, which are known to be the most important fish spoiler group. Thus, previous

14 research reports on an extension of shelf life in fish fillets [14, 15] and coated fish [16]

15 by employing LA as a previous treatment.

16 Good correlation values were obtained between the FFA content and the FR value for

17 hake $\left(r^{2}=0.91-0.93\right)$ and megrim $\left(r^{2}=0.89-0.98\right)$. Such a result has already been

18 observed in previous research in chilled lean fish species $[25,30]$ and proves a strong

19 connexion between lipid hydrolysis and oxidation. In this sense, a FFA pro-oxidant

20 effect has been explained on the basis of a catalytic effect of the carboxyl group on the

21 formation of free radicals by the decomposition of hydroperoxides [38]. On the other

22 hand, present research shows a poor correlation value between both parameters (FR and

23 FFA content $)$ in the case of angler $\left(r^{2}=0.75-0.89\right)$. This result can be explained on the

24 basis that a very low lipid oxidation development has been produced in this species

25 during the present research. 


\section{3.4. Sensory evaluation}

3 Sensory evaluation was carried out according to parameters expressed in the 4 experimental section (Table 5). Under all icing conditions, a quality decrease was 5 observed as a result of increasing the chilling time. An extended shelf life time was 6 obtained for fish kept in ice including the highest organic acid content when compared 7 to its counterpart belonging to C-400 and C-0 conditions. Under such C-800 condition, 8 hake, megrim and angler were still acceptable after 12, 8 and 12 days of chilled storage,

9 respectively. No profitable effect of C-400 condition on sensory acceptance could be 10 observed when compared to control fish.

11 Among the different kinds of molecules produced as a result of lipid damage, secondary

12 lipid oxidation compounds are considered the chief compounds responsible for oxidised

13 flavours [39]. Present research provided poor correlation values for sensory acceptance

14 with the TBA-i. This result can be explained on the basis that lipid oxidation 15 development was relatively low, so that a negligible rancid odour formation was 16 produced, according to previous research concerning hake chilling [29, 30]. Previous 17 research has shown a strong incidence of FFA accumulation on fish quality loss [40], 18 being the FFA presence associated in some extent to the lack of sensory acceptability 19 and strongly interrelated with off-odour development [41]. However, poor correlation 20 values were obtained in the present research between sensory acceptance and FFA 21 content, this result being explained again on the basis of the negligible rancid odour 22 formation. 


\section{CONCLUDING REMARKS}

2

3 The actual increasing consumer's demand for high quality fresh products has led to the

4 search for valuable and practical treatments that may provide enhancing commercial 5 possibilities. With this basic objective, the present study provides a first approach to the 6 employment of a novel strategy consisting of an icing system including a mixture of 7 organic acids (AA, CA and LA), these providing complementary preservative properties 8 (acidulants, antioxidants and antimicrobians). According to the lipid damage (hydrolysis

9 and oxidation) development in the lean fish species tested, results obtained showed a

10 positive role of the organic acid-mixture present in the icing medium, so that a partial

11 inhibition of lipid oxidation and hydrolysis development was attained. This icing

12 strategy was already tested by employing ice prepared from aqueous solutions of plant 13 extracts including polyphenolic compounds [19]; in such experiment, a partial damage 14 inhibition was produced during the chilled storage of a fatty fish species (Chilean jack 15 mackerel; Trachurus murphy).

16 Further studies focused to the positive role of this icing strategy are envisaged. A great

17 effort ought to be addressed towards knowledge of the organic acid range where optimal 18 effects could be attained [42], this including knowledge of the endogenous antioxidant 19 composition corresponding to the fish species to be tested (synergism possibility 20 analysis) and towards research checking the diffusion rate of organic acids from the 21 icing medium to the fish muscle.

22 Although most research has been previously reported for quality changes in chilled 23 Atlantic hake [29, 43, 44], studies related to the lipid fraction have been scarce and 24 incomplete $[30,31,45]$. In addition, research related to the lipid fraction damage during 25 the chilled storage of megrim [33] and angler [31] is even more scarce and incomplete. 
1 According to the results obtained in the present research, lipid hydrolysis showed to be

2 a more relevant event than lipid oxidation in all lean fish species tested.

3

4

\section{$5 \quad$ Acknowledgments}

6 The authors thank the owner and crew of the CACHACHO and CHANS ships for their

7 collaboration in the present study, and the Vigo's harbour fishing fleet in general for

8 kindly providing the different fish species. The authors also thank Mr. Marcos Trigo for

9 his excellent technical assistance and ATALANTA S. L. (Vigo, Spain) for providing the

10 commercial organic acid-mixture BPS2. Mrs. Gabriela Medina is widely acknowledged

11 for her valuable preliminary studies in applying the BPS2 product to fish. This work

12 was supported by the Secretaría Xeral de I+D from the Xunta de Galicia (Galicia,

13 Spain) through the Research Project PGIDIT 08 TAL 038E.

14

15

16 Conflict of interest statement

17 The authors have declared no conflict of interest. 


\section{FIGURE LEGENDS}

2

3

4 Figure 1: Evolution of free fatty acid (FFA) formation [g/ $100 \mathrm{~g}$ lipids]* in chilled 5

6

$7 *$ Mean values of three $(\mathrm{n}=3)$ independent determinations are given. Standard deviations

8

$9 * *$ Icing conditions as expressed in Table 1.

12 Figure 2: Evolution of free fatty acid (FFA) formation [g/ $100 \mathrm{~g}$ lipids]* in chilled megrim stored under different icing conditions**

* Mean values of three $(n=3)$ independent determinations are given. Standard deviations are denoted by bars. Starting raw fish value: $0.06 \pm 0.05$.

$17 * *$ Icing conditions as expressed in Table 1.

20 Figure 3: Evolution of free fatty acid (FFA) formation [g/ $100 \mathrm{~g}$ lipids]* in chilled angler stored under different icing conditions**

$23 *$ Mean values of three $(n=3)$ independent determinations are given. Standard deviations are denoted by bars. Starting raw fish value: $1.11 \pm 0.42$.

$25 * *$ Icing conditions as expressed in Table 1. 


\section{REFERENCES}

2

3 [1] K. Whittle, R. Hardy, G Hobbs: Chilled fish and fishery products. In: Chilled foods. 4 The state of the art. Ed. T. Gormley, Elsevier Applied Science, New York (USA) 1990, pp. 87-116.

[2] G. Olafsdóttir, E. Martinsdóttir, J. Oehlenschläger, P. Dalgaard, B. Jensen, I. Undeland, I. Mackie, G. Henehan, J. Nielsen, H. Nilsen: Methods to evaluate fish freshness in research and industry. Trends Food Sci Technol. 1997, 8, 258265.

[3] L. Toledo-Flores, R. Zall: Methods for extending the storage life of fresh tropical fish. In: Advances in Seafood Biochemistry. Eds. G. Flick, R. Martin. Technomic Publishing, Lancaster, PA (USA) 1992, pp. 233-243.

[4] I. Ashie, J. Smith, B. Simpson: Spoilage and shelf-life extension of fresh fish and shellfish. Crit Rev Food Sci Nutr. 1996, 36, 87-121.

[5] B. Ozen, J. Floros: Effects of emerging food processing techniques on the packaging materials. Trends Food Sci Technol. 2001, 12, 60-67.

[6] M. Sivertsvik, W. Jeksrud, T. Rosnes: A review of modified atmosphere packaging of fish and fishery products- significance of microbial growth, activities and safety. Int J Food Sci Technol. 2002, 37, 101-127.

[7] S. Kelleher, L. Silva, H. Hultin, K. Wilhelm: Inhibition of lipid oxidation during processing of washed, minced Atlantic mackerel. J Food Sci. 1992, 57, 11031108.

[8] H. Osborn-Barnes, C. Akoh: Copper-catalyzed oxidation of a structured lipid-based emulsion containing $\alpha$-tocopherol and citric acid: Influence of $\mathrm{pH}$ and $\mathrm{NaCl} . J$ Agric Food Chem. 2003, 51, 6851-6855. 
1 [9] K Hwang, J. Regenstein: Protection of menhaden mince lipid from rancidity during frozen storage. J Food Sci. 1988, 54, 1120-1124.

3 [10] L. Stodolnik, E. Blasiak, H. Broszedzka: Effect of Tween 80, citric acid and acetylsalicylic acids on changes in muscle tissue lipids of Baltic herrings during storage. Chlodnictwo, 1992, 27, 29-35.

[11] F. Badii, N. Howell: Effect of antioxidants, citrate, and cryoprotectants on protein denaturation and texture of frozen cod (Gadus morhua). J Agric Food Chem. 2002, 50, 2053-2061.

[12] P. Pourashouri, B. Shabanpour, S. Aubourg, J. Rohi, A. Shabani: An investigation of rancidity inhibition during frozen storage of Wels catfish (Silurus glanis) fillets by previous ascorbic and citric acid treatment. Int J Food Sci Technol. 2009, 44, 1503-1509.

[13] S. Aubourg, F. Pérez-Alonso, J. Gallardo: Studies on rancidity inhibition in frozen horse mackerel (Trachurus trachurus) by citric and ascorbic acids. Eur J Lipid Sci Technol. 2004, 106, 232-240.

[14] C. Kim, J. Hearnsberger, J. Eun: Gram-negative bacteria in refrigerated catfish fillets treated with lactic culture and lactic acid. J Food Prot. 1995, 58, 639-643.

[15] S. Metin, N. Erkan, C. Varlik, N. Aran: Extension of shelf life of chub mackerel (Scomber japonicus Houttuyn 1780) treated with lactic acid. Eur Food Res Technol. 2001, 213, 174-177.

[16] U. Gogus, F. Bozoglu, S. Yurdugul: Comparative effects of lactic acid, nisin, coating combined and alone applications on some postmortem quality criteria of refrigerated Sardina pilchardus. J Food Qual. 2006, 29, 658-671.

[17] G. Pigott, B. Tucker: Science opens new horizons for marine lipids in human nutrition. Food Rev Int. 1990, 3, 105-138. 
1 [18] A. Kolakowska: Lipid oxidation in food systems. In: Chemical and functional properties of food lipids. Eds. Z. Sikorski, A. Kolakoska, CRC Press, London (UK) 2003, pp. 133-165.

[19] V. Quitral, MaL. Donoso, J. Ortiz, Mª V. Herrera, H. Araya, S. Aubourg: Chemical changes during the chilled storage of Chilean jack mackerel (Trachurus murphyi): Effect of a plant extract-icing system. Food Sci Technol. 2009, 42, $1450-1454$.

[20] A. Madrid, J. Madrid, R. Madrid: Tecnología del pescado y productos derivados. A. Madrid Vicente, Ediciones y Mundi-Prensa Libros, S. A., Madrid (Spain),
1994, pp. 273-276.

[21] J. Giese: Antioxidants: Tools for preventing lipid oxidation. Food Technol. 1996, 50, 73-80.

[22] E. Bligh, W. Dyer: A rapid method of total extraction and purification. Can J Biochem Physiol. 1959, 37, 911-917.

[23] R. Chapman, J. McKay: The estimation of peroxides by the ferric thiocyanate method. J Amer Oil Chem Soc. 1949, 26, 360-363.

[24] W. Vyncke: Direct determination of the thiobarbituric acid value in trichloroacetic acid extracts of fish as a measure of oxidative rancidity. Fette, Seifen, Anstrichm. 1970, 72, 1084-1087.

[25] S. Aubourg, I. Medina, J Gallardo: Quality assessment of blue whiting (Micromesistius poutassou) during chilled storage by monitoring lipid damages. J Agric Food Chem. 1998, 46, 3662-3666.

23 [26] R. Lowry, I. Tinsley: Rapid colorimetric determination of free fatty acids. J Am Oil 24 Chem Soc. 1976, 53, 470-472.

25 [27] Council Regulation: Off. J. Eur. Comm. (19 February) 1990, No C84, p. 69. 
1 [28] G. Piclet: Le poisson aliment. Composition et intérêt nutritionnel. Cah Nutr Diét.

2

3

4 1987, XXII, 317-335.

[29] C. Ruiz-Capillas, A. Moral: Correlation between biochemical and sensory quality indices in hake stored in ice. Food Res Int. 2001, 34, 441-447.

[30] V. Losada, C. Piñeiro, J. Barros-Velázquez, S. Aubourg: Effect of slurry ice on chemical changes related to quality loss during European hake (Merluccius merluccius) chilled storage. Eur Food Res Technol. 2004, 219, 27-31.

[31] J. Barros-Velázquez, J. Gallardo, P. Calo, S. Aubourg: Enhanced quality and safety during on-board chilled storage of fish species captured in the Grand Sole North Atlantic fishing bank. Food Chem. 2008, 106, 493-500.

[32] N. Howell: Interaction of proteins with small molecules. In: Ingredient Interactions- Effects on Food Quality. Ed. A. Gaonkar, Marcel Dekker, New York (USA) 1995, pp. 269-289.

[33] S. Aubourg, V. Losada, J. Gallardo, M. Miranda, J. Barros-Velázquez: On-board quality preservation of megrim (Lepidorhombus whiffiagonis) by a novel ozonised-slurry ice system. Eur Food Res Technol. 2006, 223, 232-237.

[34] A. Khalil, E. Mansour: Control of lipid oxidation in cooked and uncooked refrigerated carp fillets by antioxidant and packaging combinations. J Agric Food Chem. 1998, 46, 1158-1162.

[35] Z. Sikorski, A. Kolakowska: Changes in protein in frozen stored fish. In: Seafood proteins. Eds. Z. Sikorski, B. Sun Pan, F. Shahidi, Chapman and Hall, New York (USA) 1994, pp. 99-112.

[36] T. Labuza: Kinetics of lipid oxidation in foods. CRC Crit Rev Food Technol. 1971, 2, 355-405. 
1 [37] C. Barassi, R. Pécora, H. Roldán, R. Trucco: Total, non-volatile free fatty acids as a freshness index for hake (Merluccius hubbsi) stored in ice. J Sci Food Agric. 1987, 38, 373-377.

[38] S. Aubourg: Fluorescence study of the pro-oxidant effect of free fatty acids on marine lipids. J. Sci Food Agric. 2001, 81, 385-390.

6 [39] P. White: Conjugated diene, anisidine value and carbonyl value analyses. In: Methods to assess quality and stability of oils and fat-containing foods. Eds. K. Warner, M. Eskin. AOCS Press, Champaign, Illinois, (USA) 1994, pp. 159-178.

[40] T. Ingemansson, P. Kaufmann, B. Ekstrand: Multivariate evaluation of lipid hydrolysis and oxidation data from light and dark muscle of frozen stored rainbow trout (Oncorhynchus mykiss). J Agric Food Chem. 1995, 43, 20462052.

[41] H. Refsgaard, P. Brockhoff, B. Jensen: Free polyunsaturated fatty acids cause taste deterioration of salmon during frozen storage. J Agric Food Chem. 2000, 48, $3280-3285$.

[42] Decker E, Strategies for manipulating the prooxidative/antioxidative balance of foods to maximize oxidative stability. Trends Food Sci Technol. 9, 241-248 (1998).

[43] S. Baixas-Noguera, S. Bover-Cid, T. Veciana-Nogués, C. Vidal-Carou. Chemical and sensory changes in Mediterranean hake (Merluccius merluccius) under refrigeration $\left(6-8{ }^{\circ} \mathrm{C}\right)$ and stored in ice. J Agric Food Chem. 2002, 50, 65046510.

[44] M. Tejada, A. Huidobro, G. Mohamed: Comparison of gilthead sea bream (Sparus aurata) and hake (Merluccius merluccius) muscle proteins during iced and frozen storage. J Sci Food Agric. 2003, 83, 113-122. 
1 [45] C. Ruiz-Capillas, J. Morales, A. Moral: Combination of bulk storage in controlled and modified atmospheres with modified atmosphere packaging system for chilled whole gutted hake. J Sci Food Agric. 2001, 81, 551-558.

4 
TABLE 1: Evolution of moisture content [g/ $100 \mathrm{~g}$ muscle]* in chilled fish species stored under different icing conditions**

\begin{tabular}{|c|c|c|c|c|c|c|c|}
\hline \multirow[t]{2}{*}{ Fish species } & \multirow[t]{2}{*}{ Icing condition } & \multicolumn{6}{|c|}{ Chilling storage time [days] } \\
\hline & & $\mathbf{0}$ & 1 & 5 & 8 & 12 & 15 \\
\hline \multirow{3}{*}{ Hake } & $\mathrm{C}-0$ & \multirow{3}{*}{$\begin{array}{l}79.8 \\
(0.2)\end{array}$} & $\begin{array}{l}80.8 \\
(0.3)\end{array}$ & $\begin{array}{c}82.0 \mathrm{y} \\
(0.1)\end{array}$ & $\begin{array}{l}82.0 \\
(0.1)\end{array}$ & $\begin{array}{l}82.7 \\
(0.4)\end{array}$ & $\begin{array}{l}83.0 \\
(0.8)\end{array}$ \\
\hline & $\mathrm{C}-400$ & & $\begin{array}{l}80.7 \\
(0.1) \\
\end{array}$ & $\begin{array}{c}81.4 \mathrm{yx} \\
(0.5)\end{array}$ & $\begin{array}{l}82.1 \\
(0.3) \\
\end{array}$ & $\begin{array}{l}82.2 \\
(0.4) \\
\end{array}$ & $\begin{array}{l}82.9 \\
(0.3 \\
\end{array}$ \\
\hline & C-800 & & $\begin{array}{l}80.2 \\
(0.4) \\
\end{array}$ & $\begin{array}{c}81.2 \mathrm{z} \\
(0.2)\end{array}$ & $\begin{array}{l}82.2 \\
(0.4) \\
\end{array}$ & $\begin{array}{l}82.5 \\
(0.2) \\
\end{array}$ & $\begin{array}{l}82.7 \\
(0.3) \\
\end{array}$ \\
\hline & & & & & & & \\
\hline \multirow{3}{*}{ Megrim } & $\mathrm{C}-0$ & \multirow{3}{*}{$\begin{array}{c}79.0 \\
(0.3)\end{array}$} & $\begin{array}{l}78.4 \\
(0.1) \\
\end{array}$ & $\begin{array}{l}80.7 \\
(0.2) \\
\end{array}$ & $\begin{array}{l}81.3 \\
(0.5) \\
\end{array}$ & $\begin{array}{l}82.2 \\
(0.2) \\
\end{array}$ & - \\
\hline & $\mathrm{C}-400$ & & $\begin{array}{l}78.9 \\
(0.4)\end{array}$ & $\begin{array}{l}80.4 \\
(0.4)\end{array}$ & $\begin{array}{l}81.0 \\
(0.5)\end{array}$ & $\begin{array}{l}82.0 \\
(0.2)\end{array}$ & - \\
\hline & C-800 & & $\begin{array}{l}78.8 \\
(0.2) \\
\end{array}$ & $\begin{array}{l}80.4 \\
(0.4) \\
\end{array}$ & $\begin{array}{l}80.9 \\
(0.1) \\
\end{array}$ & $\begin{array}{l}81.5 \\
(0.4) \\
\end{array}$ & - \\
\hline & & & & & & & \\
\hline \multirow{3}{*}{ Angler } & $\mathrm{C}-0$ & \multirow{3}{*}{$\begin{array}{l}81.0 \\
(0.3)\end{array}$} & $\begin{array}{c}83.6 \mathrm{y} \\
(0.8)\end{array}$ & $\begin{array}{l}83.6 \\
(0.2)\end{array}$ & $\begin{array}{c}84.3 \mathrm{y} \\
(0.2)\end{array}$ & $\begin{array}{l}84.2 \\
(0.5)\end{array}$ & - \\
\hline & $\mathrm{C}-400$ & & $\begin{array}{c}82.2 \mathrm{z} \\
(0.1)\end{array}$ & $\begin{array}{l}84.0 \\
(0.8) \\
\end{array}$ & $\begin{array}{c}84.6 \mathrm{y} \\
(0.4)\end{array}$ & $\begin{array}{l}84.5 \\
(0.5) \\
\end{array}$ & - \\
\hline & C-800 & & $\begin{array}{c}82.8 \mathrm{y} \\
(0.3)\end{array}$ & $\begin{array}{l}84.0 \\
(0.5)\end{array}$ & $\begin{array}{c}83.5 \mathrm{z} \\
(0.4)\end{array}$ & $\begin{array}{l}84.5 \\
(0.4)\end{array}$ & - \\
\hline
\end{tabular}

* Mean values of three $(n=3)$ independent determinations are expressed. Standard deviations are indicated in brackets. For each species and for each chilling time, mean values followed by different letters $(z, y, x)$ denote significant $(p<0.05)$ differences.

** Icing conditions: C-800 and C-400 (ice prepared from an aqueous solution including $800 \mathrm{ppm}$ and $400 \mathrm{ppm}$ of the organic acid-formula, respectively) and C-0 (ice prepared from water; control). 


\section{TABLE 2}

Evolution of lipid oxidation* in chilled hake stored under different icing conditions**

\begin{tabular}{|c|c|c|c|c|c|c|c|c|c|}
\hline \multirow{3}{*}{$\begin{array}{l}\text { Chilling storage time } \\
\text { [days] }\end{array}$} & \multicolumn{9}{|c|}{ Lipid oxidation assessment } \\
\hline & \multicolumn{3}{|c|}{$\begin{array}{c}\text { Peroxide value } \\
\text { [meq active oxygen/ kg lipids] }\end{array}$} & \multicolumn{3}{|c|}{$\begin{array}{c}\text { Thiobarbituric acid index } \\
\text { [mg malondialdehyde/ kg muscle] }\end{array}$} & \multicolumn{3}{|c|}{ Fluorescence ratio } \\
\hline & C-0 & C-400 & C-800 & C-0 & $\mathrm{C}-400$ & $\mathrm{C}-\mathbf{8 0 0}$ & C-0 & C-400 & C-800 \\
\hline 0 & \multicolumn{3}{|c|}{$\begin{array}{c}0.66 \\
(0.37)\end{array}$} & \multicolumn{3}{|c|}{$\begin{array}{c}0.22 \\
(0.10)\end{array}$} & \multicolumn{3}{|c|}{$\begin{array}{c}0.20 \\
(0.04)\end{array}$} \\
\hline 1 & $\begin{array}{c}0.94 \\
(0.26)\end{array}$ & $\begin{array}{c}0.76 \\
(0.43)\end{array}$ & $\begin{array}{c}0.68 \\
(0.51) \\
\end{array}$ & $\begin{array}{l}0.38 \mathrm{y} \\
(0.08)\end{array}$ & $\begin{array}{l}0.16 \mathrm{z} \\
(0.07)\end{array}$ & $\begin{array}{l}0.17 \mathrm{z} \\
(0.04)\end{array}$ & $\begin{array}{l}0.38 \mathrm{y} \\
(0.02)\end{array}$ & $\begin{array}{l}0.26 \mathrm{z} \\
(0.05)\end{array}$ & $\begin{array}{l}0.35 \mathrm{yz} \\
(0.05)\end{array}$ \\
\hline 5 & $\begin{array}{l}2.92 \mathrm{x} \\
(0.77)\end{array}$ & $\begin{array}{l}1.59 \mathrm{y} \\
(0.29)\end{array}$ & $\begin{array}{l}0.95 \mathrm{z} \\
(0.21)\end{array}$ & $\begin{array}{l}0.36 \mathrm{y} \\
(0.11)\end{array}$ & $\begin{array}{l}0.20 \mathrm{yz} \\
(0.07)\end{array}$ & $\begin{array}{l}0.19 \mathrm{z} \\
(0.04)\end{array}$ & $\begin{array}{c}0.15 \\
(0.04)\end{array}$ & $\begin{array}{c}0.14 \\
(0.05)\end{array}$ & $\begin{array}{c}0.17 \\
(0.05)\end{array}$ \\
\hline 8 & $\begin{array}{c}2.53 \mathrm{yz} \\
(0.58)\end{array}$ & $\begin{array}{l}3.54 \mathrm{y} \\
(0.51)\end{array}$ & $\begin{array}{l}2.74 \mathrm{z} \\
(0.21)\end{array}$ & $\begin{array}{c}0.53 \\
(0.32)\end{array}$ & $\begin{array}{c}0.55 \\
(0.25)\end{array}$ & $\begin{array}{c}0.44 \\
(0.07)\end{array}$ & $\begin{array}{c}0.28 \\
(0.16)\end{array}$ & $\begin{array}{c}0.22 \\
(0.13)\end{array}$ & $\begin{array}{c}0.15 \\
(0.06)\end{array}$ \\
\hline 12 & $\begin{array}{c}3.85 \mathrm{yz} \\
(1.06)\end{array}$ & $\begin{array}{l}4.98 \mathrm{y} \\
(0.35)\end{array}$ & $\begin{array}{l}3.44 \mathrm{z} \\
(0.17)\end{array}$ & $\begin{array}{l}0.82 \mathrm{y} \\
(0.42)\end{array}$ & $\begin{array}{c}0.79 y \\
(0.17)\end{array}$ & $\begin{array}{l}0.32 \mathrm{z} \\
(0.18)\end{array}$ & $\begin{array}{l}0.94 \mathrm{y} \\
(0.17)\end{array}$ & $\begin{array}{l}0.55 \mathrm{z} \\
(0.15)\end{array}$ & $\begin{array}{l}0.44 \mathrm{z} \\
(0.09)\end{array}$ \\
\hline 15 & $\begin{array}{l}4.72 \mathrm{y} \\
(1.17)\end{array}$ & $\begin{array}{c}4.01 \mathrm{yz} \\
(1.01)\end{array}$ & $\begin{array}{c}2.86 \mathrm{z} \\
(0.49)\end{array}$ & $\begin{array}{l}0.43 \mathrm{y} \\
(0.06)\end{array}$ & $\begin{array}{l}0.29 \mathrm{z} \\
(0.05)\end{array}$ & $\begin{array}{c}0.27 \mathrm{z} \\
(0.08)\end{array}$ & $\begin{array}{l}2.65 \mathrm{y} \\
(0.43)\end{array}$ & $\begin{array}{l}1.13 \mathrm{z} \\
(0.36)\end{array}$ & $\begin{array}{c}0.80 \mathrm{z} \\
(0.16)\end{array}$ \\
\hline
\end{tabular}

* Mean values of three $(n=3)$ independent determinations are expressed. Standard deviations are indicated in brackets. For each parameter and for each chilling time, mean values followed by different letters $(z, y, x)$ denote significant $(p<0.05)$ differences.

** Icing conditions (C-0, C-400 and C-800) as expressed in Table 1. 


\section{TABLE 3}

\section{Evolution of lipid oxidation* in chilled megrim stored under different icing conditions**}

\begin{tabular}{|c|c|c|c|c|c|c|c|c|c|}
\hline \multirow{3}{*}{$\begin{array}{c}\text { Chilling storage time } \\
\text { [days] }\end{array}$} & \multicolumn{9}{|c|}{ Lipid oxidation assessment } \\
\hline & \multicolumn{3}{|c|}{$\begin{array}{c}\text { Peroxide value } \\
\text { [meq active oxygen/ kg lipids] }\end{array}$} & \multicolumn{3}{|c|}{$\begin{array}{c}\text { Thiobarbituric acid index } \\
\text { [mg malondialdehyde/ kg muscle] }\end{array}$} & \multicolumn{3}{|c|}{ Fluorescence ratio } \\
\hline & $\mathrm{C}-\mathbf{0}$ & $\mathrm{C}-400$ & C-800 & C-0 & $\mathrm{C}-400$ & C-800 & C-0 & C-400 & C-800 \\
\hline 0 & \multicolumn{3}{|c|}{$\begin{array}{c}2.79 \\
(1.12)\end{array}$} & \multicolumn{3}{|c|}{$\begin{array}{c}0.21 \\
(0.05)\end{array}$} & \multicolumn{3}{|c|}{$\begin{array}{c}0.08 \\
(0.20)\end{array}$} \\
\hline 1 & $\begin{array}{c}2.33 \\
(0.79)\end{array}$ & $\begin{array}{c}2.04 \\
(0.55)\end{array}$ & $\begin{array}{c}2.19 \\
(0.21)\end{array}$ & $\begin{array}{l}0.29 \mathrm{y} \\
(0.07)\end{array}$ & $\begin{array}{l}0.16 \mathrm{z} \\
(0.04)\end{array}$ & $\begin{array}{l}0.22 \mathrm{yz} \\
(0.15)\end{array}$ & $\begin{array}{c}0.90 \\
(0.15)\end{array}$ & $\begin{array}{c}0.75 \\
(0.02)\end{array}$ & $\begin{array}{c}0.83 \\
(0.09)\end{array}$ \\
\hline 5 & $\begin{array}{c}2.68 \\
(0.99)\end{array}$ & $\begin{array}{c}2.79 \\
(0.25)\end{array}$ & $\begin{array}{c}1.89 \\
(0.64)\end{array}$ & $\begin{array}{c}0.31 \\
(0.08)\end{array}$ & $\begin{array}{c}0.44 \\
(0.09)\end{array}$ & $\begin{array}{c}0.45 \\
(0.10)\end{array}$ & $\begin{array}{c}1.85 \\
(0.41)\end{array}$ & $\begin{array}{c}1.76 \\
(0.35)\end{array}$ & $\begin{array}{c}1.91 \\
(0.36)\end{array}$ \\
\hline 8 & $\begin{array}{c}5.78 \\
(0.49)\end{array}$ & $\begin{array}{c}4.76 \\
(0.21)\end{array}$ & $\begin{array}{c}3.37 \\
(1.05)\end{array}$ & $\begin{array}{c}0.62 \\
(0.19)\end{array}$ & $\begin{array}{c}0.50 \\
(0.16)\end{array}$ & $\begin{array}{c}0.48 \\
(0.09)\end{array}$ & $\begin{array}{l}3.62 \mathrm{y} \\
(0.23)\end{array}$ & $\begin{array}{l}2.03 \mathrm{z} \\
(0.48)\end{array}$ & $\begin{array}{c}2.22 \mathrm{z} \\
(0.38)\end{array}$ \\
\hline 12 & $\begin{array}{l}3.57 \mathrm{z} \\
(0.73)\end{array}$ & $\begin{array}{l}7.03 \mathrm{y} \\
(0.57)\end{array}$ & $\begin{array}{l}4.58 \mathrm{z} \\
(0.41)\end{array}$ & $\begin{array}{c}0.37 \mathrm{z} \\
(0.08)\end{array}$ & $\begin{array}{c}0.96 \mathrm{y} \\
(0.03)\end{array}$ & $\begin{array}{l}0.44 \mathrm{z} \\
(0.11)\end{array}$ & $\begin{array}{l}7.09 \mathrm{y} \\
(1.35)\end{array}$ & $\begin{array}{l}3.88 \mathrm{z} \\
(1.14)\end{array}$ & $\begin{array}{c}2.99 \mathrm{z} \\
(0.53)\end{array}$ \\
\hline
\end{tabular}

* Mean values of three $(\mathrm{n}=3)$ independent determinations are expressed. Standard deviations are indicated in brackets. For each parameter and for each chilling time, mean values followed by different letters $(z, y)$ denote significant $(p<0.05)$ differences.

** Icing conditions (C-0, C-400 and C-800) as expressed in Table 1. 


\section{TABLE 4}

Evolution of lipid oxidation* in chilled angler stored under different icing conditions**

\begin{tabular}{|c|c|c|c|c|c|c|c|c|c|}
\hline \multirow{3}{*}{$\begin{array}{c}\text { Chilling storage time } \\
\text { [days] }\end{array}$} & \multicolumn{9}{|c|}{ Lipid oxidation assessment } \\
\hline & \multicolumn{3}{|c|}{$\begin{array}{c}\text { Peroxide value } \\
\text { [meq active oxygen/ kg lipids] }\end{array}$} & \multicolumn{3}{|c|}{$\begin{array}{c}\text { Thiobarbituric acid index } \\
\text { [mg malondialdehyde/ kg muscle] }\end{array}$} & \multicolumn{3}{|c|}{ Fluorescence ratio } \\
\hline & C-0 & $\mathrm{C}-400$ & C-800 & C-0 & $\mathrm{C}-400$ & C-800 & C-0 & C-400 & C-800 \\
\hline 0 & \multicolumn{3}{|c|}{$\begin{array}{c}1.49 \\
(0.57)\end{array}$} & \multicolumn{3}{|c|}{$\begin{array}{c}0.10 \\
(0.08)\end{array}$} & \multicolumn{3}{|c|}{$\begin{array}{c}0.37 \\
(0.09)\end{array}$} \\
\hline 1 & $\begin{array}{c}2.48 \\
(0.40)\end{array}$ & $\begin{array}{c}2.09 \\
(0.50)\end{array}$ & $\begin{array}{c}2.35 \\
(0.19)\end{array}$ & $\begin{array}{c}0.06 \\
(0.01)\end{array}$ & $\begin{array}{c}0.08 \\
(0.01)\end{array}$ & $\begin{array}{c}0.14 \\
(0.08)\end{array}$ & $\begin{array}{l}0.35 \mathrm{z} \\
(0.10)\end{array}$ & $\begin{array}{l}0.31 \mathrm{z} \\
(0.10)\end{array}$ & $\begin{array}{l}0.55 \mathrm{y} \\
(0.03)\end{array}$ \\
\hline 5 & $\begin{array}{c}2.81 \\
(0.24)\end{array}$ & $\begin{array}{c}2.44 \\
(0.48)\end{array}$ & $\begin{array}{c}2.63 \\
(0.36)\end{array}$ & $\begin{array}{c}0.11 \\
(0.03)\end{array}$ & $\begin{array}{c}0.10 \\
(0.03)\end{array}$ & $\begin{array}{c}0.08 \\
(0.03)\end{array}$ & $\begin{array}{c}0.38 \\
(0.06)\end{array}$ & $\begin{array}{c}0.45 \\
(0.08)\end{array}$ & $\begin{array}{c}0.43 \\
(0.04)\end{array}$ \\
\hline 8 & $\begin{array}{c}3.94 \mathrm{yz} \\
(0.62)\end{array}$ & $\begin{array}{l}4.81 \mathrm{y} \\
(0.86)\end{array}$ & $\begin{array}{l}2.97 \mathrm{z} \\
(0.70)\end{array}$ & $\begin{array}{c}0.09 \\
(0.02)\end{array}$ & $\begin{array}{c}0.16 \\
(0.08)\end{array}$ & $\begin{array}{c}0.12 \\
(0.08)\end{array}$ & $\begin{array}{c}0.80 \\
(0.09)\end{array}$ & $\begin{array}{c}0.78 \\
(0.07)\end{array}$ & $\begin{array}{c}0.71 \\
(0.30)\end{array}$ \\
\hline 12 & $\begin{array}{l}3.51 \mathrm{y} \\
(0.21)\end{array}$ & $\begin{array}{c}2.60 \mathrm{yz} \\
(0.80)\end{array}$ & $\begin{array}{l}2.39 \mathrm{z} \\
(0.54)\end{array}$ & $\begin{array}{c}0.03 \mathrm{z} \\
(0.01)\end{array}$ & $\begin{array}{c}0.12 \mathrm{y} \\
(0.05)\end{array}$ & $\begin{array}{c}0.07 \mathrm{yz} \\
(0.04)\end{array}$ & $\begin{array}{c}0.93 \\
(0.25)\end{array}$ & $\begin{array}{c}1.13 \\
(0.31)\end{array}$ & $\begin{array}{c}0.80 \\
(0.31)\end{array}$ \\
\hline
\end{tabular}

* Mean values of three $(n=3)$ independent determinations are expressed. Standard deviations are indicated in brackets. For each parameter and for each chilling time, mean values followed by different letters $(z, y)$ denote significant $(p<0.05)$ differences.

** Icing conditions (C-0, C-400 and C-800) as expressed in Table 1. 


\section{TABLE 5}

Evolution of sensory quality* in chilled fish species stored under different icing conditions $^{* *}$

\begin{tabular}{|c|c|c|c|c|c|c|c|}
\hline \multirow{2}{*}{$\begin{array}{c}\text { Fish } \\
\text { species }\end{array}$} & \multirow{2}{*}{$\begin{array}{c}\text { Icing } \\
\text { condition }\end{array}$} & \multicolumn{6}{|c|}{ Chilling storage time [days] } \\
\hline & & $\mathbf{0}$ & $\mathbf{1}$ & 5 & 8 & 12 & 15 \\
\hline \multirow{3}{*}{ Hake } & $\mathrm{C}-0$ & $\mathrm{E}$ & A & $\mathrm{B}$ & $\mathrm{B}$ & $\mathrm{C}$ & $\mathrm{C}$ \\
\hline & $\mathrm{C}-400$ & $\mathrm{E}$ & $\mathrm{A}$ & $\mathrm{A}$ & B & $\mathrm{C}$ & $\mathrm{C}$ \\
\hline & $\mathrm{C}-800$ & $\mathrm{E}$ & $\mathrm{A}$ & $\mathrm{A}$ & B & $\mathrm{B}$ & $\mathrm{C}$ \\
\hline \multirow{3}{*}{ Megrim } & $\mathrm{C}-0$ & A & A & $\mathrm{B}$ & $\mathrm{C}$ & $\mathrm{C}$ & - \\
\hline & $\mathrm{C}-400$ & A & $\mathrm{A}$ & $\mathrm{B}$ & $\mathrm{C}$ & $\mathrm{C}$ & - \\
\hline & $\mathrm{C}-800$ & A & A & $\mathrm{B}$ & $\mathrm{B}$ & $\mathrm{C}$ & - \\
\hline \multirow{3}{*}{ Angler } & $\mathrm{C}-0$ & A & A & $\mathrm{B}$ & $\mathrm{B}$ & $\mathrm{C}$ & - \\
\hline & $\mathrm{C}-400$ & $\mathrm{~A}$ & $A$ & $\mathrm{~B}$ & B & $\mathrm{C}$ & - \\
\hline & C-800 & $\mathrm{A}$ & A & $\mathrm{A}$ & $\mathrm{A}$ & B & - \\
\hline
\end{tabular}

* Quality categories: E (highest), A (good), B (fair) and C (unacceptable).

** Icing conditions as expressed in Table 1. 
Figure 1 $69 \times 40 \mathrm{~mm}(600 \times 600$ DPI $)$ 


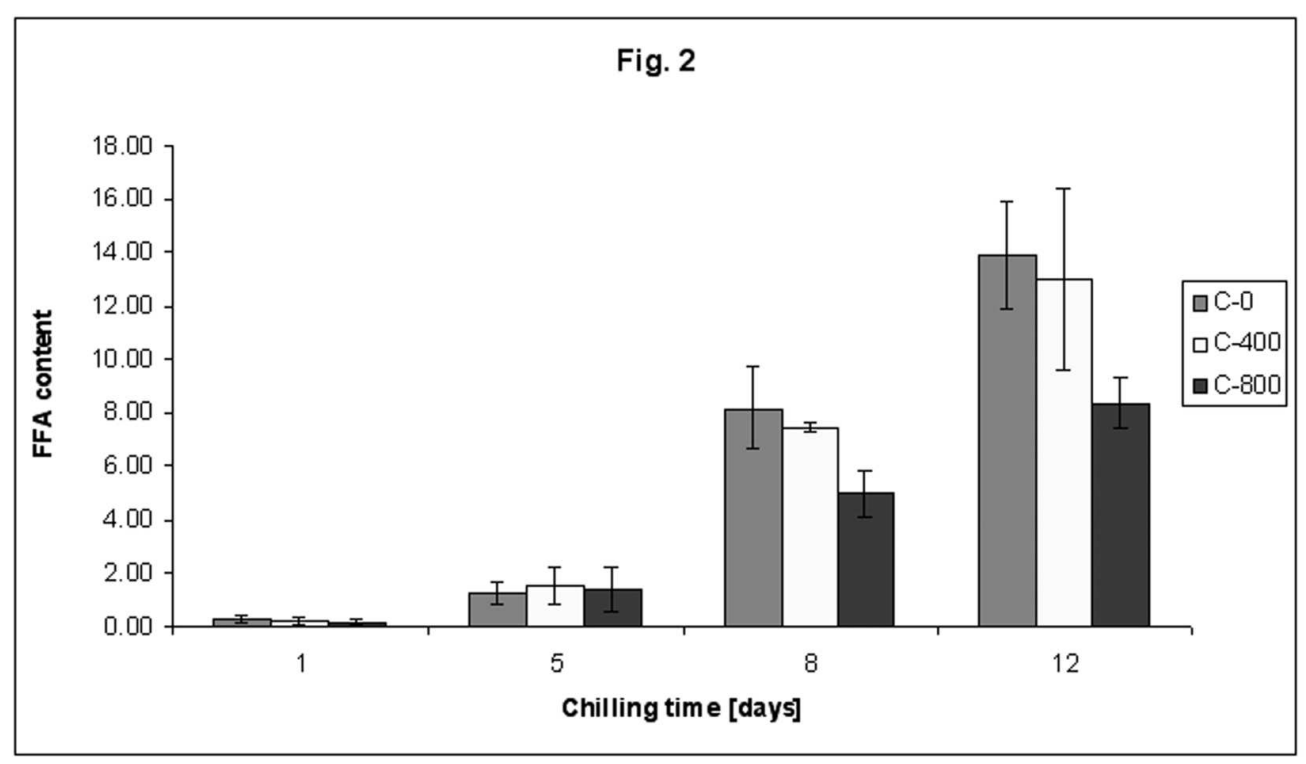

Figure 2

$69 \times 40 \mathrm{~mm}(600 \times 600$ DPI $)$ 
Fig. 3

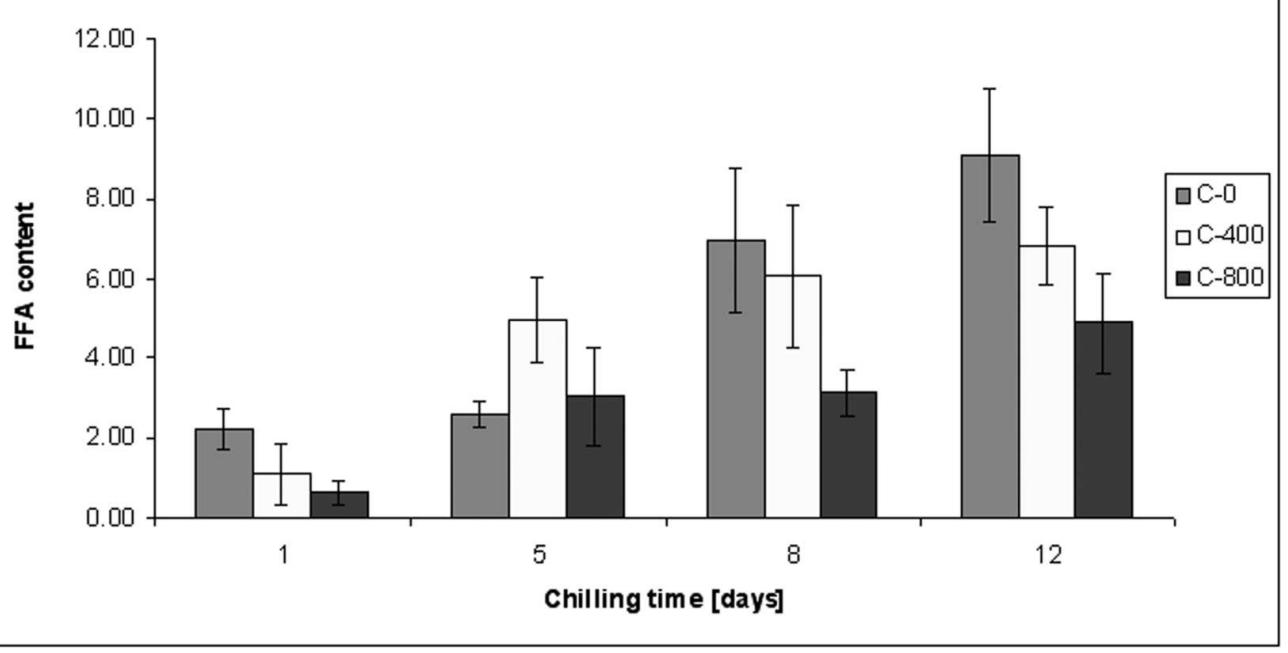

Figure 3

$69 \times 40 \mathrm{~mm}(600 \times 600 \mathrm{DPI})$ 